\title{
APP Gene
}

National Cancer Institute

\section{Source}

National Cancer Institute. APP Gene. NCI Thesaurus. Code C28537.

This gene is involved in transcriptional activation and mutations in the gene are correlated with Alzheimer disease. 